\title{
Optimization of Proteins Recovery Process from Cheese
}

\section{Whey}

Cuellas Anahí ${ }^{1}$, Jagus Rosa ${ }^{2}$ and Wagner Jorge ${ }^{1,3}$

1. Department of Science and Technology, National University of Quilmes, Roque Sáenz Peña 352, Bernal B1876BXD, Buenos Aires, Argentina

2. Laboratory of Industrial Microbiology, Department of Chemical Engineering, Engineering Faculty, Universidad de Buenos Aires, Av. Intendente Güiraldes 2620, Ciudad Universitaria C1428EGA, CABA Buenos Aires, Argentina

3. National Council of Scientific and Technical Research (CONICET), Av. Rivadavia 1917, C1033AAJ, CABA Buenos Aires, Argentina

\begin{abstract}
The process to obtain a protein-containing ingredient from the remaining whey of Argentinean "Cuatriolo" cheese production was studied. In order to optimize the protein recovery, physical and chemical treatments were investigated. Two protocols with different sequences of application of heating step and acid addition were assayed in the presence and absence of fat and $\mathrm{CaCl}_{2}$. The results were evaluated by the yield, water retention and particle size. The results showed that the highest yield of the process $(76.6 \%)$ and an increase in water retention $(39.8 \mathrm{w} / \mathrm{w})$ were achieved when the acid was added after boiled and incubated for $30 \mathrm{~min}$ at $90{ }^{\circ} \mathrm{C}$. In these working conditions, the presence of calcium shows a lower yield of recovery $(72.8 \%)$ and this behaviour correlates with a smaller particle size. Additionally, the presence of fat reduces the particle size and decreases the performance of the process (69.4\%). Thus, the yield of protein recovery is related to the particle size of the aggregates, i.e., the recovery of proteins increases when increase the particle size. The simultaneous presence of fat and $\mathrm{CaCl}_{2}$ increases the amount of water retained in the aggregated protein $(47.62 \mathrm{w} / \mathrm{w})$. In conclusion, the process of aggregation in whey protein should take into account both the design of suitable protocol and the presence of fat and additives.
\end{abstract}

Key words: Cheese whey, whey proteins recovery, physical treatments, chemical treatments.

\section{Introduction}

Cheese whey is the main by-product in the manufacture of cheese. It has a severe problem because of its high biological oxygen demand (35-60 $\mathrm{g} / \mathrm{L}$ ). Hence, there is an increasing need to develop methods for making use of cheese whey - a nutritional by-product, in order to avoid the negative environmental implications and give a better economic return $[1,2]$.

In Argentina, $50 \%$ of milk production is destined for cheese making [3]. According to the Ministry of Agriculture, Livestock and Fisheries, local cheese production is close to 500 thousand tons and is

Corresponding author: Cuellas Anahí, professor, research fields: food technology, enzyme technology and food biotechnology. E-mail: acuellas@unq.edu.ar. classified as soft $(50 \%)$, semi-hard $(35 \%)$ and hard $(15 \%)$. Argentinean "Cuatriolo" is the most important within the soft cheese pasta [4].

Whey proteins are important in the food industry, not only as components of dairy products, but also as ingredients in non-dairy food products. They are widely used due to their high nutritional quality, desirable sensory characteristics and high techno functional potentiality $[5,6]$. The most abundant whey proteins- $\beta$-lactoglobulin ( $\beta$-Lg) and $\alpha$-lactalbumin $(\alpha-\mathrm{La})$, contribute greatly to the functional properties of whey ingredients and have been studied in great detail. Heat-induced unfolding and aggregation of $\beta-\mathrm{Lg}$ alone have been widely studied in the past years [7]. The process encompasses two steps: during the first step, the proteins can be partially or totally 
unfolded by denaturation, which is induced by heating, addition of chemicals, change in net charge, etc.; during the second step, denatured whey protein molecules aggregate through physical (electrostatic and hydrophobic) and chemical (disulphide) interactions, thus leading to formation of a crosslinked, three-dimensional network [8].

Whey protein denaturation begins with the initial swelling of the protein structure when it is first exposed to heat. As the intensity of the heat treatment increases, the whey proteins unfold, aggregate and form sediments through a multiple-reaction process. In general, for protein precipitation, the authors recommend to adjust the $\mathrm{pH}$ of whey between 6.3 and 6.8 using $\mathrm{NaOH}$ solution, then heat it to $90{ }^{\circ} \mathrm{C}$ and acidize it to $\mathrm{pH}$ between 4.5 and $5.5[9,10]$.

Denaturation/aggregation phenomena depend on physical and biochemical parameters, such as heating temperature and holding time, heating rate, presence of proteins or other hydrocolloids, protein concentration, $\mathrm{pH}$, ionic strength and mineral content $[5,7,9]$. Even though there are many studies about the optimization of the process of aggregation of whey proteins, no results were found about the influence of the presence of residual fat on it.

Taking into account the importance of aggregation of whey proteins to the valuation of the effluent, the authors in the research included the study of the influence of residual fat on the process and its interaction with $\mathrm{CaCl}_{2}$. The objective of this work was to obtain protein aggregates with high yield and good water retention capacity. These features would allow to develop products with better properties and also could reduce the volume of dairy whey generated.

\section{Materials and Methods}

The whey from "Cuartirolo" cheese elaboration process was used. Average composition of the whey used in this work is shown in Table 1. Total solid, protein and fat (in the aqueous phase) were determined according to standard procedures AOAC
[11]. The $\mathrm{pH}$ value was recorded using a digital $\mathrm{pH}$ meter (Hanna HI99163, Rumany) equipped with an electrode (FC232D, Italy). Fat removal was carried out by centrifugation at $3,000 \times \mathrm{g}$ and filtration with filter paper.

\subsection{Protein Coagulation Process}

Two protocols with different sequences of application of heating step and acid addition were assayed:

Protocol I: heat the whey until boiling, lead to $\mathrm{pH}$ 4.6 with acetic acid and keep the heating to $90{ }^{\circ} \mathrm{C}$ in thermostatic bath for $30 \mathrm{~min}$.

Protocol II: heat the whey until boiling, holding at $90{ }^{\circ} \mathrm{C}$ in thermostatic bath for $30 \mathrm{~min}$ and lead to $\mathrm{pH}$ 4.6 with acetic acid.

The influence of addition of $\mathrm{CaCl}_{2}$ in the aggregation process was evaluated on protocols I and II. Samples I $\mathrm{Ca}$ and II $\mathrm{Ca}$ were obtained by addition of $\mathrm{CaCl}_{2}(200 \mathrm{mg} / \mathrm{mL})$ in the acidification step. Additionally, in the protocol II, the addition of $\mathrm{CaCl}_{2}$ was evaluated before the holding to $90{ }^{\circ} \mathrm{C}$, resulting the sample II Ca'.

The influence of fat in the whey was evaluated in all conditions (samples: I fat, II fat, I Ca-fat, II Ca-fat and II Ca'-fat). Samples I fat and II fat were idem to sample II without fat elimination. Sample II Ca-fat was idem to sample II $\mathrm{Ca}$ without fat elimination. Finally, the samples were subjected to centrifugation at 3,000 $\times \mathrm{g}$ and the protein aggregates were removed from the supernatant by filtration cotton cloth, resulting the samples I and II corresponding to the mentioned protocols, respectively.

Table 1 Average composition of cheese whey used for obtaining protein aggregates.

\begin{tabular}{ll}
\hline Parameters & Whey \\
\hline $\mathrm{pH}$ & $6.56 \pm 0.05$ \\
Fat $(\mathrm{g} / 100 \mathrm{~g})$ & $0.86 \pm 0.01$ \\
Protein $(\mathrm{g} / 100 \mathrm{~g})$ & $0.95 \pm 0.02$ \\
Solids-not fat $(\mathrm{g} / 100 \mathrm{~g})$ & $5.75 \pm 0.10$ \\
Total solids $(\mathrm{g} / 100 \mathrm{~g})$ & $6.61 \pm 0.11$ \\
\hline
\end{tabular}




\subsection{Protein Content Determination}

$50 \mathrm{~mL}$ of trichloroacetic acid (24\%) was added to $50 \mathrm{~mL}$ of sample (whey or supernatant) and kept $1 \mathrm{~h}$ at $4{ }^{\circ} \mathrm{C}$. Then it was centrifuged at $5,300 \times \mathrm{g}$ for 10 $\min$ at $4{ }^{\circ} \mathrm{C}$. The precipitate was washed with ethanol-ethyl ether $(1: 1)$, and centrifuged under identical conditions. Finally, it was brought to original volume with $\mathrm{NaOH} 0.1 \mathrm{~N}$. Protein determination was performed by the method of Lowry et al. [12].

\subsection{Yield and Water Retention of Protein Aggregates}

The yield was determined from the relationship between precipitated protein and whey protein ( $\mathrm{g}$ of precipitated proteins/g of whey proteins), where precipitate protein was calculated as the difference of protein content in whey and supernatant after precipitation process.

The water retention capacity was determined from the ratio of water contained in wet precipitate and precipitated proteins. It can be calculated as the Eq. (1):

$$
\text { water retention capacity }=
$$

( $g$ of wet precipitate $-g$ of precipitated proteins) $\times$

$$
100 / g \text { of precipitated proteins }
$$

\subsection{Particle Size Distribution}

The particle size distribution of aqueous dispersion of precipitates was determined in the diameter range of $0.1-1,000 \mu \mathrm{m}$ by laser scattering using a Malvern Mastersizer 2000E (Malvern Instruments Ltd., Worcestershire, UK). Samples were dispersed in the water bath of the dispersion system at 2,000 rpm (Hydro 2000MU). Optical parameters applied were: refractive indexes of particle and water 1.53 and 1.33 , respectively and adsorption coefficient 0.001 . Particle size distributions were expressed in number (\%) and volume $(\%)$. The De Brouker mean diameter $\left(D_{4,3}\right)$ was determined from volume distribution, while the percentile diameter $\left(d_{0.9}\right)$ was obtained from number distribution; it means the value below $d_{0.9}$ lies $90 \%$ of the particles.

\subsection{Transmission Electron Microscopy}

Transmission electron microscopy (TEM) was carried out on the aqueous dispersion of precipitates. Samples were collected on copper grids and subsequently stained using saturated uranyl acetate solution for $1 \mathrm{~min}$. The electron microscope (Phillips EM-301, Netherlands) was operated at $60 \mathrm{kV}$. A magnification of $10,000 \times-46,000 \times$ was employed. Micrographs were taken from different areas of the sample grid and three or four images were acquired using digital image capture system.

\section{Results and Discussion}

\subsection{Yield and Water Retention of Protein Aggregates}

The performance of the protein aggregation process can be analyzed in bases of the yield of protein recovery and water retention capacity (Table 2). Comparison between samples I and II showed that a heat denaturation process previous to acetic acid addition (protocol II), allows to obtain a better protein recovery with a higher water retention capacity of aggregates. This behavior was observed in both samples with remaining fat and samples without fat.

Since whey proteins are relatively low molecular weight and soluble at its isoelectric point [13], a thermal treatment is necessary to precipitate them [14]. During this process, $\beta-\mathrm{Lg}$ (the major component of whey proteins) undergoes a structural change - exposes

Table 2 Yield and water retention capacity of protein aggregates during protein recovery process from cheese whey.

\begin{tabular}{lll}
\hline Sample & Yield $(\% \mathrm{w} / \mathrm{w})$ & $\begin{array}{l}\text { Water retention capacity } \\
(\% \mathrm{w} / \mathrm{w})\end{array}$ \\
\hline I & $64.7 \pm 2.4$ & $9.3 \pm 0.2$ \\
I Ca & $70.5 \pm 1.9$ & $19.8 \pm 0.5$ \\
I fat & $62.4 \pm 2.2$ & $9.0 \pm 0.2$ \\
I Ca-fat & $69.6 \pm 1.7$ & $17.0 \pm 0.6$ \\
II & $76.6 \pm 2.3$ & $40.0 \pm 1.0$ \\
II Ca & $72.8 \pm 2.1$ & $32.2 \pm 0.9$ \\
II fat & $69.4 \pm 1.6$ & $46.6 \pm 1.2$ \\
II Ca-fat & $69.1 \pm 1.4$ & $41.0 \pm 0.8$ \\
II Ca' & $68.1 \pm 1.7$ & $15.5 \pm 0.4$ \\
II Ca'-fat & $69.3 \pm 1.2$ & $16.7 \pm 0.3$ \\
\hline
\end{tabular}


the S-S groups, which play a central role in the formation of covalent "bridges" with other proteins. These structural changes are produced quickly to $\mathrm{pH}$ values greater than 6.7 and temperatures above $70{ }^{\circ} \mathrm{C}$ [9]. Also, Robinson et al. [15] suggested that the increase of protein recovery is directly related to whey exposure time at $90{ }^{\circ} \mathrm{C}$, and $10 \mathrm{~min}$ of heating is sufficient to reach the maximum performance.

Calcium is not involved in denaturalization process, but it takes part in the aggregation of denatured proteins. The calcium ion can form internal electrostatic bridges to intervene in the structure of the aggregates [15]. Thus, the observed differences in performance were dependent on the protocol followed. In the sample I $\mathrm{Ca}$, increased yield and water retention were observed. However, the presence of $\mathrm{CaCl}_{2}$ in protocol II did not enhance the protein recovery and reduced water retention. Changes in the results depend not only on the presence of calcium, but they also depend on when it is added. II Ca' sample showed a water retention capacity much smaller than sample II $\mathrm{Ca}$, indicating that calcium is less effective when the whey proteins are not denatured prior.

The alone presence of fat does not modify the water retention of the sample I fat (respect to sample I). However, protocol II shows an increase in water retention in the presence of fat. It should be noted that the fat globules may be retained in the network and thus increase the weight of wet precipitate. In protein denaturation, the protein is unfolded and exposed outside their hydrophobic groups and acquires a random conformation, which depends upon the intensity of treatment. If the acid is immediately added after this step, the three-dimensional network would not include fat globules inside. Furthermore, if after denaturation, the whey proteins stay at $90{ }^{\circ} \mathrm{C}$ during $30 \mathrm{~min}$, the degree of denaturation increases and the hydrophobic residues would be more prone to interact with the fat globules. These residues may interact with the lipids, and in the second stage of aggregation, fat globules could be retained in the network and thus increase the weight of the wet pellets. The unfolding of the native structure of proteins promotes the establishment of hydrophobic interactions and disulfide bonds with protein molecules, carbohydrates and lipids [16].

According to the results observed, the presence of fat in samples I and II interferes with the formation of protein aggregates, resulting in a lower yield. This result agrees with previous works, whereas the higher fat content in samples appeared to inhibit the flocculant action [17].

In the first protocol, the sample with calcium and fat has more water retention than samples without $\mathrm{Ca}$ (II and II fat), but the retention capacity is slightly smaller than the sample with only $\mathrm{Ca}$. The simultaneous presence of fat and $\mathrm{CaCl}_{2}$ (II Ca-fat) in protocol II did not change water retention with respect to the sample II, but increased their capacity with respect to the sample containing only calcium (II Ca), and decreased with respect to that containing only fat (II fat). The addition of calcium salt after warming affects this behavior, showing lower water retention in sample II Ca', with respect to these three samples.

\subsection{Particle Size Distribution}

Different protocols and their influence on the aggregate size, performance and the water retention capacity were analyzed. The particle size distribution was analyzed in the samples that showed the most interesting results. The distribution of particle size of protocols I and II, which is expressed as volume (\%), is shown in Fig. 1. It is important to note that these results correspond to the protein aggregates resistant to the agitation process during particle size measurement.

A higher particle size could be a consequence of a higher hydration degree of particles, which was clearly observed in the water retention capacity of samples I and II (9.4\% and $41.7 \%$, respectively).

The analysis of the samples obtained with the process I (Fig. 1a) shows that only I and I Ca have a 


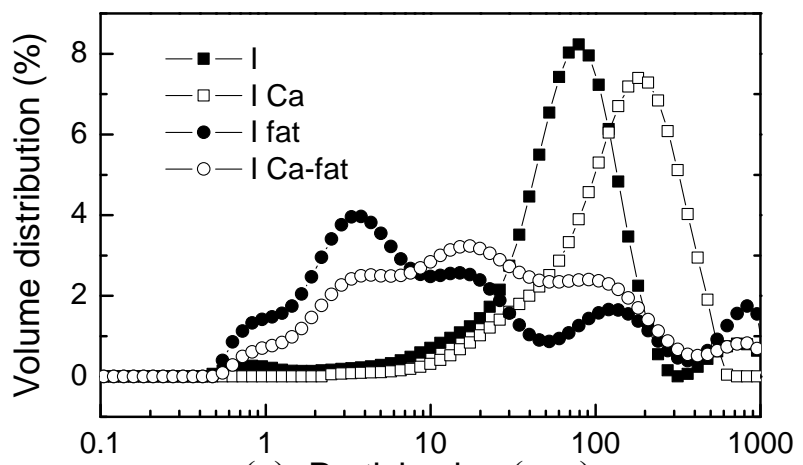

(a) Particle size $(\mu \mathrm{m})$

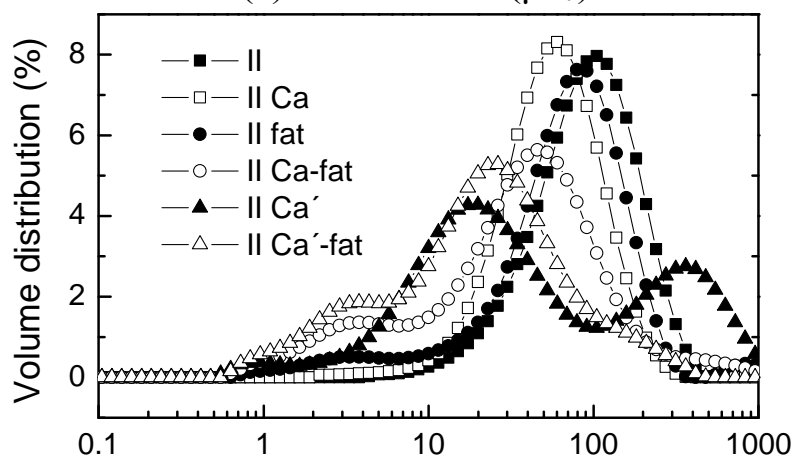

(b) Particle size ( $\mu \mathrm{m})$

Fig. 1 Particle size distribution expressed in volume for whey protein aggregates obtained from protocols $I$ (a) and II (b).

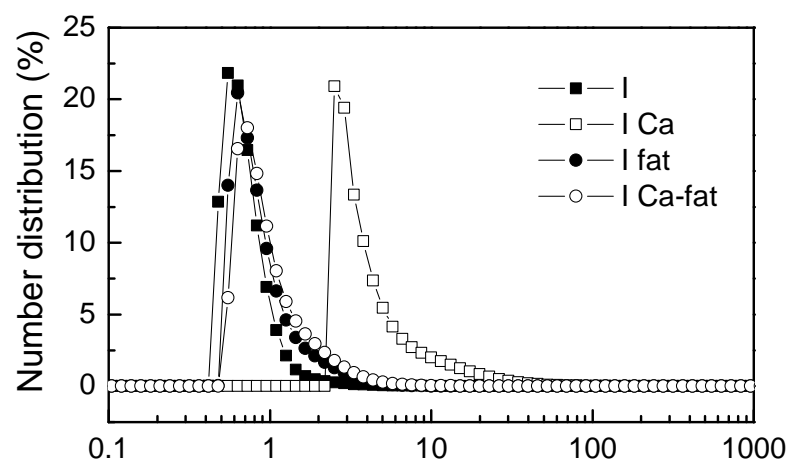

(a) Particle size $(\mu \mathrm{m})$

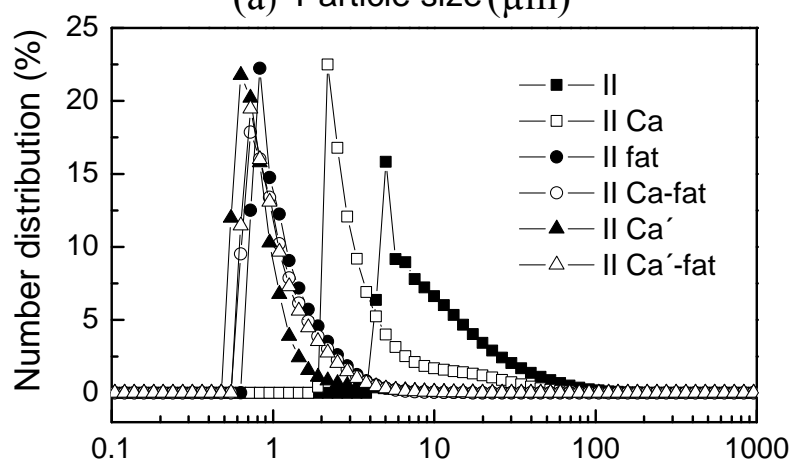

(b) Particle size ( $\mu \mathrm{m})$

Fig. 2 Particle size distribution expressed in number for whey protein aggregates obtained from protocols $I$ (a) and II (b). monomodal behavior, while the presence of fat causes multimodal particle size distributions. Among the samples obtained from procedure I, I Ca shows the highest $D_{4,3}(152.8 \pm 10.4 \mu \mathrm{m})$, indicating that the presence of particles occupies a high hydrodynamic volume, which coincides with its high water retention capacity (Table 2). $D_{4,3}$ values of the remaining samples are less than $78 \mu \mathrm{m}$. For protocol II, samples II and II $\mathrm{Ca}$ also exhibit monomodal volume distribution. The $D_{4,3}$ values are $78.0 \pm 1.2 \mu \mathrm{m}$ and $105.5 \pm 2.5 \mu \mathrm{m}$, respectively, while other samples show values of $D_{4,3}<68 \mu \mathrm{m}$. Moreover, samples II and II $\mathrm{Ca}$ exhibit high water retention capacity (Table 2), which would indicate some relationship between the volume occupied by the particles and the water content. The values of $D_{4,3}$ and the water retention capacity of the sample II fat are also high. However, these values can be overestimated due to the presence of fat.

Moreover, when the particle size distribution was expressed in number (\%), samples I Ca, II and II Ca are those with $\mathrm{Ca}$ protein aggregates with larger diameter (Figs. 2a and 2b).

The yield of protein recovery would be related to the particle size of the aggregates, expressed as a percentile $d_{0.9}$; an increase in the particle size produces an increase in the recovery of proteins (Fig. 3).

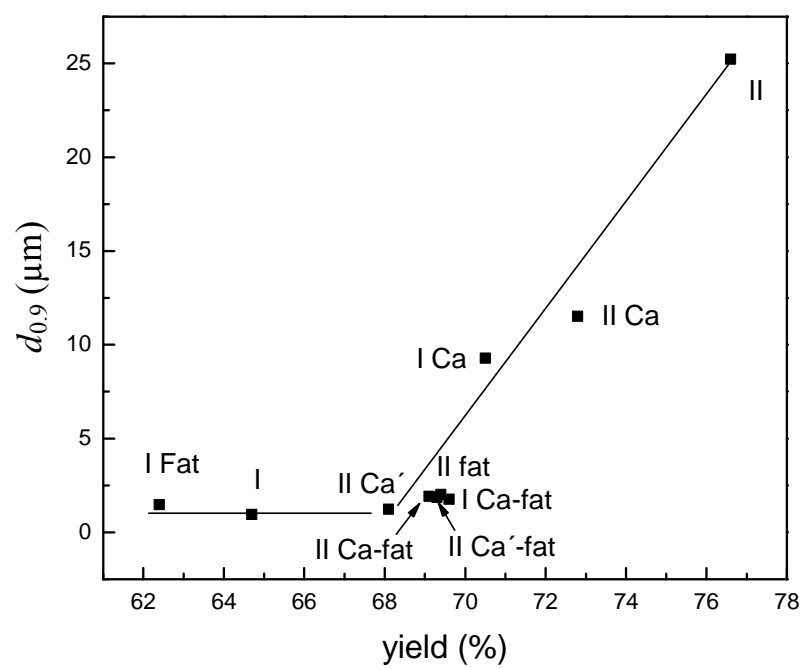

Fig. 3 Relationships between the protein recovery yield and the values of percentile diameter of whey protein particles. 

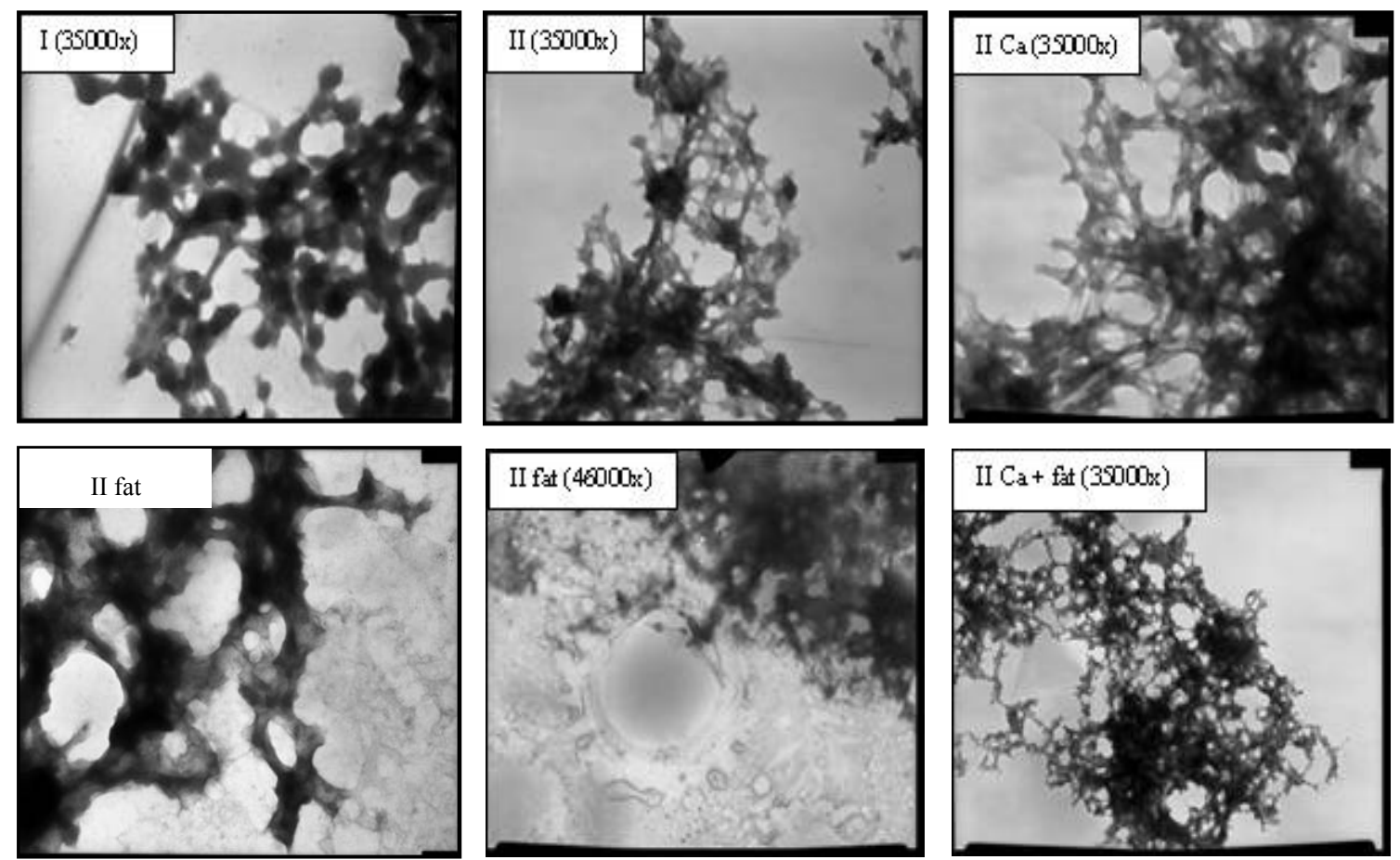

Fig. 4 Electron micrographs of protein aggregates after different protocols.

The results show that the protein aggregates have populations with different particle size, but the majority population is the one with smaller particles. On one hand, larger aggregates are more stable than the smaller aggregates; on the other hand these latter may be formed in the stirring process.

\subsection{Transmission Electron Microscopy (TEM)}

The TEM are shown in Fig. 4. Electron micrographs of aggregates allow to see that sample I is composed of aggregates with enclosed structure. This spatial arrangement of aggregates could explain the low water retention of the protein precipitate with protocol I. On the other hand, the protein aggregates obtained from protocol II have a net-like open structure, which is capable of occluding water.

In the presence of calcium salts, small aggregates formed larger cross-linked aggregates. Heat-induced aggregation of proteins is driven by hydrophobic interaction, which is associated with the creation of a strong gel network due to additional cross-linking via formation of calcium bridges between protein molecules [18]. The joint action of the hydrophobic interactions and $\mathrm{Ca}^{++}$bridges formed aggregates more compact, smaller in diameter and with less water retention.

The micrograph of sample II fat shows that fat interferes with the three-dimensional precipitate structure. These results are correlated correctly with the water retention capacity of the different aggregates [19].

Finally, samples with calcium and fat have a strong network structure type with aggregates of smaller diameter (which agrees with the size distribution in Fig. 2b) and consequently a slight lower water retention capacity (Table 2 ).

\section{Conclusions}

The potential nutritional benefits of whey proteins have been subject of growing commercial interest. Whey proteins can be incorporated in the form of ingredients in functional and novel foods, dietary supplements and even pharmaceutical with the purpose of delivering specific health benefits. As result, they can be used as a basic compound of functions foods, nutraceuticals and dietary 
supplements. On the other hand, the design of products that take advantage of cheese whey is important, in order to avoid the negative environmental implications and give a better economic return.

Taking into account these issues, the authors evaluated physical and chemical treatments to obtain a protein-containing ingredient from the remaining whey of Argentinean "Cuatriolo" cheese. The results showed that the highest yield of the process and an increase in water retention are achieved when the acid is added after whey protein denaturalization at $90{ }^{\circ} \mathrm{C}$ for $30 \mathrm{~min}$. This temperature value used was determined to be optimal in previous papers. The simultaneous presence of fat and $\mathrm{CaCl}_{2}$ increases the amount of water retained in the aggregated protein. Therefore, the process of aggregation in whey protein should take into account both the design of suitable protocol and the presence of fat and additives.

Hence, the results show that the optimization of the aggregation process is a good tool to reduce the volume of effluent from the cheese industry. On the other hand, it provides a new alternative to produce protein ingredients for use in the food industry.

\section{References}

[1] Smithers, G. W. 2008. "Whey and Whey Proteins-From 'Gutter-to-Gold'.” Int. Dairy Journal 18: 695-704.

[2] Atra, R., Vatai, G., Bekassy-Molnar, E., and Balint, A. 2006. "Investigation of Ultra- and Nanofiltration for Utilization of Whey Protein and Lactose." J. of Food Eng. 67 (3): 325-32.

[3] Cuellas, A., Oddone, S., Mammarella, E., and Rubiolo, A. 2013. "Hydrolysis of Lactose: Estimation of Kinetic Parameters Using Artificial Neural Networks." Journal of Agricultural Science and Technology A 3: 811-8.

[4] Argentinean Ministry of Agriculture, Livestock, Fisheries and Food (SAGPyA). "Estadisticas 2012." Accessed September,

2013. http://64.76.123.202/site/_subsecretaria_de_lecheria/lech eria/07_Estadísticas/index.php.

[5] Hoffmann, M. A., Sala, G., Olieman, C., and Kruif, K. G. 1997. "Molecular Mass Distributions of Heat-Induced $\beta$-Lactoglobulin Aggregates.” J. Agri. Food Chem. 45 (8): 2949-57.

[6] Flett, K. L., and Corredig, M. 2009. "Whey Protein
Aggregate Formation during Heating in the Presence of K-Carrageenan.” Food Chemistry 115 (4): 1479-85.

[7] Durand, D., Gimel, J. C., and Nicolai, T. 2002. "Aggregation, Gelation and Phase Separation of Heat Denatured Globular Proteins." Physica A 304 (1-2): 253-65.

[8] Ramos, O. L., Pereira, J. O., Silva, S. L., Amorim, M. M., Fernandes, J. C., Lopes-Silva, J. A., Pintado, M. E., and Malcata, F. X. 2012. "Effect of Composition of Commercial Whey Protein Preparations upon Gelation at Various pH Values.” Food Research International 48 (2): 681-9.

[9] Gracia-Julia, A., Rene, M., Cortes-Munoz, M., Picart, L., Lopez-Pedemonte, T., Chevalier, C., and Dumay, E. 2008. "Effect of Dynamic High Pressure on Whey Protein Aggregation: A Comparison with the Effect of Continuous Short-Time Thermal Treatments." Food Hydrocolloids 22 (6): 1014-32.

[10] Hollar, C. M., Parris, N., Hsieh, A., and Cockley, K. D. 1995. "Factors Affecting the Denaturation and Aggregation of Whey Proteins in Heated Whey Protein Concentrate Mixtures." J. Dairy Sci. 78 (2): 260-7.

[11] AOAC. 1995. Official Methods of Analysis, 16th ed.. Washington, DC: Assoc. Off. Anal. Chem..

[12] Lowry, O. H., Rosebrough, N. J., Farr, A. L., and Randall, R. J. 1951. "Protein Measurement with the Folin Phenol Reagent.” J. Biol. Chem. 193: 265-75.

[13] Dissanayake, M., Liyanaarachchi, S., and Vasiljevic, T. 2012. "Functional Properties of Whey Proteins Microparticulated at Low pH." Journal of Dairy Science 95 (4): 1667-79.

[14] Hill, A. R., Irvine, D. M., and Bullock, D. H. 1982. "Precipitation and Recovery of Whey Proteins: A Review." Can. Inst. Food Sci. Technol. J. 15 (3): 155-60.

[15] Robinson, B. P., Short, J. L., and Marshall, K. R. 1976. "Traditional Lactalbumin Manufacture, Properties and Uses." New Zealand J. Dairy Sci. Technol. 11 (2): 114-26.

[16] Guckian, S., Dwyer, C., and O'Sullivan, M. 2005. "Properties and Mechanisms of Protein Interactions in Films Formed from Different Proportions of Heated and Unheated Whey Protein Solutions." Food Hydrocolloids 223 (1): 91-5.

[17] Ryan, K. N., Vardhanabhuti, B., Jaramillo, D. P., Van Zanten, J. H., Coupland, J. N., and Foegeding, E. A. 2012. "Stability and Mechanism of Whey Protein Soluble Aggregates Thermally Treated with Salts." Food Hydrocolloids 27 (2): 411-20.

[18] Solak, B., and Akin, N. 2012. "Health Benefits of Whey Protein: A Review." Journal of Food Science and Engineering 2: 129-37. 
[19] Vázquez-Puente, F., Villegas-Arroyo, G. A., and Mosqueda-Frías, P. R. 2010. "Precipitation of Whey Proteins as a Function of Acidity, Temperature and Time from Whey Produced in Comonfort, Guanajuato, Mexico." Revista Venezolana de Ciencia y Tecnología de Alimentos 1 (2): 157-69. 